\title{
THE CORRELATION BETWEEN PATIENT SATISFACTION AND PEOPLE EQUITY AMONG PARAMEDIC STAFFS IN INPATIENT ROOMS
}

\author{
Hubungan Kepuasan Pasien dengan People Equity Tenaga Paramedis di Ruang \\ Rawat Inap Rumah Sakit Islam Surabaya
}

*Sendhi Tristanti Puspitasari

Faculty of Sport Science, Malang State University, Indonesia

${ }^{*}$ Correspondence: dr.sendhi@gmail.com

\begin{abstract}
Background: One of the elements controlling the quality of hospital health services is patient and employee satisfaction. The mean value of patient satisfaction with all parameters of inpatient rooms at the Islamic Hospital in Surabaya from January to August 2016 was $61.3 \%$ which is less than the standard of $\geq 90 \%$. Whereas, people equity is a concept of human resource management that signs organizational performance.

Aims: This study examined the correlation between patient satisfaction and people equity among paramedic staffs especially in inpatient rooms of the Islamic Hospital in Surabaya.

Methods: This study focused on measuring people equity, patient satisfaction, and the correlation between people satisfaction and people equity. The questionnaire used in this study adopted RATER dimensions (Reliability, Assurance, Tangible, Empathy, and Responsiveness).

Results: The study found that three inpatient rooms (Muzdalifah, Arofah, and Shofa) did not meet three elements of people equity (Alignment, Capabilities, and Engagement). Patient satisfaction with the inpatient rooms was good, except for the tangible dimension especially room cleanliness which is still relatively low. People equity among the paramedic staff has strong relevance and is directly proportional to patient satisfaction with the inpatient rooms of the Islamic Hospital in Surabaya.

Conclusion: Internalizing an organizational culture that considers patient satisfaction and patient equity among paramedic staffs is essential to harmonize the goals, vision, and mission between the hospital and its staffs. This study recommends that there should be a more serious evaluation of the cleanliness of all service units at the Islamic Hospital in Surabaya.
\end{abstract}

Keywords: Patient satisfaction, People equity, Human Resource Management, Service performance.

\section{ABSTRAK}

Latar Belakang: Salah satu elemen kontrol kualitas pelayanan rumah sakit adalah kepuasan pasien dan pekerja. Nilai rata-rata kepuasan pasien dengan parameter ruang rawat inap di Rumah Sakit Islam Surabaya dari Januari hingga Agustus 2016 adalah 61.3\%, lebih rendah dari standard nilai 90\%. Sementara itu, people equity adalah konsep pengelelolaan sumber daya manusia yang menunjukkan kinerja organisasi.

Tujuan: Penelitian ini bertujuan untuk menguji hubungan antara kepuasan pasien dan people equity di antara pekerja paramedis terutama di ruang rawat inap Rumah Sakit Islam di Surabaya.

Metode: Penelitian ini berfokus pada pengukuran people equity, penilaian kepuasan pasien, dan pengaruh kepuasan orang terhadap people equity. Angket yang digunakan dalam penelitian ini mengadopsi dimensi RATER (Reliability, Assurance, Tangible, Empathy, dan Responsiveness).

Hasil: Studi ini menemukan bahwa 3 kamar rawat inap (Muzdalifah, Arofah, dan Shofa) tidak memenuhi 3 elemen dari people equity (Keselarasan (Alignment), Kapabilitas (Capabilities), dan Keterikatan (Engagement)). Kepuasan pasien telah tercapai dengan baik di ruang rawat inap Rumah Sakit Islam di Surabaya, kecuali untuk dimensi Tangible terutama dalam aspek kebersihan kamar yang masih relatif rendah. People Equity dari staf pekerja medis memiliki relevansi yang kuat dan berbanding lurus dengan kepuasan pasien di ruang rawat inap Rumah Sakit Islam di Surabaya.

Kesimpulan: Internalisasi budaya organisasi sangat penting untuk menyelaraskan tujuan, visi dan misi antara rumah sakit dan staf. Studi ini merekomendasikan bahwa harus ada evaluasi yang lebih serius pada sektor kebersihan semua unit layanan di Rumah Sakit Islam Surabaya.

Kata Kunci: Kepuasan pasien, People equity, Manajemen sumber daya manusia, Kinerja pelayanan. 


\section{INTRODUCTION}

Patient satisfaction is "fulfillment of or meeting one's expectations about a service or product" (Chu and Khong, 2018; Vinodkumar et al., 2018). It has been argued that patients and their relatives expect good clinical care as well as good facilities during their visit to a hospital. These may be useful markers of service quality (Mishra and Mishra, 2014). Patient satisfaction is more vital specifically in developing countries. It is both as a service quality indicator and a quality component. A strong healthcare system enables healthcare providers to deliver better quality and value to patients (Camgöz-Akdağ and Zineldin, 2010).

Customer satisfaction can be improved by refining the driving factors and triggering the employee capability values. Human Resources "People Equity" was coined by William A. Schiemann in 2006. The People Equity theory explains about the quality of human resources in a company which consists of employee disharmony, ability and involvement (Schiemann, 2006).

People equity plays an important role in financial performance, quality, customer loyalty, and retention of talented employees. People Equity can be applied to all ownership of private and government organizations or profit or non-profit organizations. Alignment, Capability and Engagement as the dimensions of people equity have an influence on the organization's business results (Schiemann, 2006).
Patient satisfaction is affected by external and internal factors. External factors come from patients, government policies and various socio-culture. While, the use of RATER (Reliable, Assurance, Tangible, Emphaty and Responsiveness) is used to measure the intrinsic factors of the patient (Parasuraman, 1998).

Table 1 shows that the mean of patient satisfaction with all inpatient room service parameters at the Islamic Hospital in Surabaya from January to August 2016 was $61.3 \%$. The value of patient satisfaction was less than the standard from the Regulation of Indonesian Health Ministry Number 129 the Year 2008 about patient satisfaction in an inpatient room (90\%).

Various factors influence patient satisfaction. (a) First, it can be from a stimulus that the customer receives well through the senses of eyes, ears, taste, smell, and touch. (b) Patient assessment or value judgment can be stated in the attributes of good, bad, positive, negative, or neutral attitudes of patients towards the health services they receive. (c) Patients' reaction in the aspect of affection and cognition can be feelings of satisfaction, dissatisfaction, happiness, unhappiness, anger or sadness, and (d) Different individual characteristics of each patient also impact patient satisfaction, such as predisposing factors (age, sex), previous health behaviors and personal experience in previous health services (Ramsheoek et al., 2010).

Table 1. Patient Satisfaction in the Inpatient Rooms from January to August 2016.

\begin{tabular}{|c|c|c|c|c|c|c|c|c|c|}
\hline \multirow[t]{2}{*}{ Indicator } & \multicolumn{8}{|c|}{ Month (\%) } & \multirow[t]{2}{*}{ Mean (\%) } \\
\hline & Jan & Feb & March & April & May & June & July & August & \\
\hline Admission & 62 & 76 & 62 & 55.3 & 63.5 & 68.8 & 62 & 67 & 64.5 \\
\hline Facilities & 54 & 62 & 53 & 51.0 & 52.7 & 40.7 & 53 & 50 & 52.0 \\
\hline Paramedics & 72 & 85 & 63 & 60.0 & 75.4 & 74.4 & 75 & 63 & 71.0 \\
\hline Physician & 62 & 73 & 53 & 52.5 & 59.3 & 66.0 & 77 & 57 & 62.5 \\
\hline Pharmacy & 49 & 39 & 44 & 40.0 & 35.3 & 36.8 & 73 & 47 & 45.5 \\
\hline Laboratory & 60 & 63 & 59 & 57.3 & 61.0 & 67.4 & 88.2 & 83 & 67.4 \\
\hline Radiology & 63 & 60 & 52 & 59.0 & 60.4 & 57.4 & 87 & 75 & 64.1 \\
\hline Cashier & 62 & 60 & 49 & 53.6 & 55.3 & 60.4 & 70 & 67 & 59.7 \\
\hline Customer care & 94 & 79 & 73 & 92.5 & 90.8 & 89.3 & 0 & 0 & 64.8 \\
\hline & & & Overall & sfaction & & & & & 61.3 \\
\hline
\end{tabular}

Table 2. Recapitulation of Patient Satisfaction Based on Dimensions of Reliability, Empathy, Assurance, Responsiveness, and Tangibility.

\begin{tabular}{cccccccc}
\hline Room & Reliability & Empathy & Assurance & Responsiveness & Tangibility & Mean & Level \\
\hline Muzdalifah & 3.55 & 3.48 & 3.35 & 3.13 & 3.27 & 3.36 & $\begin{array}{c}\text { Quite } \\
\text { Satisfied }\end{array}$ \\
\hline Mina & 3.73 & 3.54 & 3.58 & 3.25 & 3.35 & 3.49 & Satisfied \\
\hline Multazam & 3.57 & 3.62 & 3.55 & 3.33 & 3.27 & 3.47 & Satisfied \\
\hline Arofah & 3.57 & 3.64 & 3.28 & 3.56 & 3.50 & 3.51 & Satisfied \\
\hline Shofa & 3.78 & 3.64 & 3.50 & 3.32 & 3.30 & 3.51 & Satisfied \\
\hline Zam - zam & 3.52 & 3.52 & 3.50 & 3.50 & 2.81 & 3.37 & $\begin{array}{c}\text { Quite } \\
\text { Satisfied }\end{array}$ \\
\hline Hijir Ismail & 3.61 & 3.36 & 3.58 & 3.71 & 3.36 & 3.52 & Satisfied \\
\hline
\end{tabular}


METHOD

This study used primary data through a survey to 70 medical staffs (nurses and midwives) and 128 patients, and the secondary data were obtained from the reports in the Department of Public Relations, Medical Services, and Human Resources. This study used a questionnaire adopting RATER dimensions (Reliability, Assurance, Tangibility, Empathy, and Responsiveness) developed by Schiemann (2006). RATER serves to measure patients' satisfaction about the quality of the performance of human resources in a company. The quality of performance was reviewed using three components of people equity, namely Alignment, Capability and Employee Engagement (Schiemann, 2006)

The parameters used in the reliability aspect are time discipline, the accuracy of action, standard operating procedures, and the flow of service delivery. The parameters used in the assurance aspect are the truth and information given to patients, hospitality, attention, and courtesy of the paramedics given to patients. The tangible aspect used some parameters, such as medical devices owned by the inpatient unit, the operational feasibility of medical devices provided by the inpatient unit, and the neatness and cleanliness of the inpatient rooms. Moreover, the empathy aspect has several parameters including the use of service assistance provided by the paramedics in the inpatient unit, communication between paramedics and patients, and patient or family understanding of medical services provided by the paramedics. In terms of the responsiveness, the paramaters are measured from the speed of paramedics and the readiness of the paramedics in serving the needs of patients (Parasuraman, 1998).

To measure the people equity in the inpatient unit, the raters measure patient satisfaction, one of which relates to easy access to paramedics and information request, patient satisfaction with the sophistication and feasibility of medical equipment, patient satisfaction with room cleanliness, patient satisfaction with timeliness of services for patient needs, patient satisfaction with the speed of services in carrying out actions in accordance with the incharge doctors' instruction to patients. The function of the raters depends on the needs, plays as an appraisal of the developed instrument or observation instrument. In this study,the raters were used to assess patient satisfaction based on three target people equity (Alignment, Capability, and Engagement).

\section{RESULTS AND DISCUSSION}

\section{Patient Satisfaction}

Table 2 shows that the Muzdalifah Room has the lowest level of patient satisfaction approximately at 3.36, compared to the other inpatient rooms at the Islamic Hospital in Surabaya. It seems very contradictory since the Muzdalifah Room is a VIP inpatient room at the Islamic Hospital in Surabaya. While, out of five indicators used, the tangible dimension in the aspect of room cleanliness has a very low value of 2.59 on average.

Table 3. People Equity Profile Assessed by the Paramedics.

\begin{tabular}{|c|c|c|c|c|c|}
\hline Room & Alignment & Capabilities & Engagement & Mean & People Equity Profile \\
\hline \multirow[t]{2}{*}{ Muzdalifah } & 3.73 & 3.34 & 3.45 & 3.51 & Indifferent \\
\hline & High & Low & Low & & \\
\hline \multirow{2}{*}{ Mina } & 4.00 & 3.12 & 4.08 & 3.73 & Under Equipped \\
\hline & High & Low & High & & \\
\hline \multirow[t]{2}{*}{ Multazam } & 3.89 & 3.61 & 4.03 & 3.84 & Under Equipped \\
\hline & High & Low & High & & \\
\hline \multirow[t]{2}{*}{ Arofah } & 4.04 & 3.41 & 3.95 & 3.80 & Indifferent \\
\hline & High & Low & Low & & \\
\hline \multirow[t]{2}{*}{ Shofa } & 4.21 & 3.52 & 3.91 & 3.88 & Indifferent \\
\hline & High & Low & Low & & \\
\hline \multirow[t]{2}{*}{ Zam - Zam } & 3.71 & 3.41 & 4.01 & 3.71 & Under Equipped \\
\hline & High & Low & High & & \\
\hline \multirow[t]{2}{*}{ Hijir Ismail } & 4.03 & 3.93 & 3.96 & 3.97 & Under Achiever \\
\hline & High & High & Low & & \\
\hline
\end{tabular}

\section{People Equity}

In the people equity assessment, the dimensions used have their own criteria. Alignment will be considered low when the value is $<3.68$, and it will be said to be high for the value of $\geq 3.68$. Capability value is low when they are $<3.84$, and it will be high when the value is $\geq 3.84$. Whereas employee engagement is low when the value is $<4.01$, and it will be considered high when the value is $\geq 4.01$. Table 3 shows the people equity profiles in the Muzdalifah, Arofah, and Shofa Rooms are indifferent. These three rooms have the same value of people equity. The under-equipped rooms are Mina, Multazam, and Zam-Zam. The capabilities of the paramedics in these rooms are low because their competencies are not suitable with the needs of inpatient rooms. The underachieved profile means that the value of effective paramedics is low, such as 
that in Hijr Ismail' Room. Average people equity is the value in each inpatient room which consists of alignment, capability, and engagement. The mean value of people equity will be used to find out the relationship between people equity and patient satisfaction. The categories used in Table 3 are based on Schiemann (2006) as the rating was explained in Table 4 ( $A=$ Alignment, $C=$ Capabilities, and $\mathrm{E}=$ Engagement).

Table 4 displays eight ACE framework. Each of them has a negative impact on the organization and the individual. For example, in the category ofunder-equipped profile, skills, teamwork, information or resources may be insufficient to meet customer's expectations (Schiemann, 2013). The "under achiever" knows what need to be done and has skills to do it but lacks motivation or interest in the issues. Talent waste occurs when the organization has created a strong and well-matched talent pool with its strategy and its customers but has failed to align or motivate the talents effectively (Schiemann, 2006).

Table 4. People Equity Profile.

\begin{tabular}{cccc}
\hline A & C & E & PEP \\
\hline High & High & High & $\begin{array}{c}\text { Superior } \\
\text { performance }\end{array}$ \\
\hline Low & Low & High & Pollyana \\
\hline High & Low & High & $\begin{array}{c}\text { Under } \\
\text { Equipped }\end{array}$ \\
\hline Low & High & High & $\begin{array}{c}\text { Strategic } \\
\text { Disconnect }\end{array}$ \\
\hline High & High & Low & $\begin{array}{c}\text { Under } \\
\text { Achiever }\end{array}$ \\
\hline High & Low & Low & Indifferent \\
\hline Low & High & Low & Talent waste \\
\hline Low & Low & Low & $\begin{array}{c}\text { Performance } \\
\text { Laggard }\end{array}$ \\
\hline
\end{tabular}

\section{The Correlation of Patient Satisfaction with People Equity}

The statistical test on the correlation of people equity and patient satisfaction obtained a Pearson correlation r-value of 0.829 and a sig (2-tailed) value of 0.021 . It means correlated if $r$ value is $>0.5$. The sig (2-tailed) value gives a significant correlation if the result is $<0.05$. It means that people equity from the paramedics has a significant relationship with patient satisfaction in the inpatient rooms of the Islamic Hospital in Surabaya.

Human resources are organizational resources that contribute to achieve competitively advantagious positions (Carmelli, 2004). Human resource management requires human capital in an organization. Human capital is a productive potential of action and knowledge that is beneficial to an organization (Kreitner and Kinicki, 2007). The human capital theory explains that investment in knowledge and expertise can provide benefits (Becker, 1993).

The specific aspect of human capital that is currently popular to be studied is people equity, a concept of human resource management, which consists of alignment, capabilities, and engagement (Diharto et al., 2017). The application of people equity can result in the increase of hospital productivity, reduce the employee turnover rates, and thus create brand equity, product value, and relationship value (Finney, 2008; Schiemann, 2006).

The triggers of alignment are primarily a clear vision and strategy. Many organizations have neatly arranged strategies. However, they often have not been approved and derived into clear definitions both in-process and behavior. As a result, the strategies are perceived differently by employees. Management needs to translate vision and strategies into concrete measures for the unit and organization (Kumar et al., 2013). The strategies should provide an overview of "what will" and "do not do". The "do not do" part is the key to alignment because it helps to reduce the amount of energy wasted by doing low-value activities (Schiemann, 2006).

Table 5. Correlation Test Results.

\begin{tabular}{llcc}
\hline & & $\begin{array}{c}\text { Patient } \\
\text { Satisfaction }\end{array}$ & $\begin{array}{c}\text { People } \\
\text { Equity }\end{array}$ \\
\hline $\begin{array}{l}\text { Patient } \\
\text { Satisfaction }\end{array}$ & $\begin{array}{l}\text { Pearson } \\
\text { Correlation }\end{array}$ & 1 & $.829^{*}$ \\
\hline & $\begin{array}{l}\text { Sig. (2- } \\
\text { tailed) }\end{array}$ & 021 \\
\hline $\begin{array}{l}\text { People } \\
\text { Equity }\end{array}$ & $\begin{array}{l}\text { Pearson } \\
\text { Correlation }\end{array}$ & $.829^{*}$ & 1 \\
\hline & $\begin{array}{l}\text { Sig. (2- } \\
\text { tailed) }\end{array}$ & .021 & \\
\hline & $\mathrm{N}$ & 7 & 7 \\
\hline
\end{tabular}

Compatibility or alignment involves the employees' understanding of hospital goals and strategies as well as the clarity of commitment to patients (Schiemann, 2006). In this study, alignment is measured from three parameters, such as understanding of vision and mission, the purpose of work, and the achievement of hospital goals. The respondents' understanding of the goals and common vision and mission at all units was good. Such understanding is needed so that all directions and target planning are in accordance with the hospital's vision and mission. In terms of the work units, each room has good objectives related to the hospital's vision and mission. The synergy between the vision and mission of the rooms and the organization is very much needed in carrying out daily tasks so that the alignment will occur between individual paramedics, inpatient rooms, and hospital. Most of the inpatient rooms have decent facilities. Appropriate facilities can improve the performance of paramedics in serving patients in each room as to how they create patient satisfaction. In terms of paramedical commitment in upholding and guaranteeing the confidentiality of patients in each room, it shows good results. However, this study showed that patient satisfaction with 
cleanliness in the inpatient unit of the hospital is very low. Cleanliness in the inpatient unit is very lacking, so it is necessary to carry out supervision and evaluation of infrastructure used for cleaning services, resources involved and guidance from the leadership regarding this matter (Puspitasari, 2018)

The capabilityof development strategy has to be clearly defined to suit the organizational capability in facilitating the development design approach to ensure its sustainabiility. In the long run, it is insufficient to have a strong capability of development strategy. Thus, in this context, the organization shall also be resourceful to manage the total capability of workforce (Kumar et al., 2013). Employee capability is one of the most important factors in predicting customer loyalty, retention, and value. While engagement and alignment affect profitability, efficiency, and outcome, capability is directly correlated with the product or service that a customer receives. Alignment is a focus, and engagement is energy, and capabilities are skills. Then, technology and processes need to provide products and services to customers. The capability gap is detrimental to a company because employees do not have skills needed according to their roles and responsibilities. As a result, the company has to incur additional costs to overcome these capability gaps (Finney, 2008; Schiemann, 2006).

Meeting the patients' needs, the paramedics should have the ability of "caring" as mutually nurturing relationships among individuals based on a sense of commitment and responsibility (Phillips, 1993). Furthermore, Swanson's Caring Theory explained that the capability of paramedics could be measured by identifying their ability, knowing what they do for, and understanding how they enable and maintain beliefs. The results of this study indicated that the overall capability of paramedics requires more serious attention than other dimensions of people equity. The paramedics at Hijr Ismail Room had the highest capability. In the other six rooms, they had a low capacity (Swanson, 2013).

Low capability can be caused by a lack of competence or incompatible competencies of the paramedics. The paramedics' competencies should be matched to types of patients treated in each room. Low capability can decrease patient satisfaction because of unfulfilled needs by the paramedics in the inpatient rooms. The low capability also causes bad profile of people equity so that it can also threaten the hospital's stakeholder equity.

Engagement is an attitude of employees who are engaged wholeheartedly to carry out tasks voluntarily and show little prohibited behavior. The Institute of Employment Studies describes engagement as a positive attitude towards the company. Engagement is a state of emotional and intellectual commitment to a company or group, and it produces behaviors that will help to fulfill the company's promise to customers (Kreitner and Kinicki, 2007). The employees who are satisfied with their company will have a low level of stress and high commitment as well as excellent advocacy. At a higher level, the employees' commitment to the company occurs because the company has identified their roles (Schiemann, 2006).

The engagement questioned in this study is the engagement of body and soul as well as the employee pride towards their organization (Schiemann, 2006). In this study, the engagement was measured by four parameters, namely satisfaction with the Islamic Hospital in Surabaya as a workplace, joy in carrying out tasks at the work unit, hospital treatment on patients, and opportunities for learning and developing while working at the Islamic Hospital in Surabaya.

Apparently, the paramedics were satisfied with their work unit. One important factor in the human resource management of an organization is job satisfaction among employees. Employees or paramedics in this study were satisfied with the compatibility of their competence, skills and expectations for their job at hand. Satisfaction is actually a subjective condition as a result of comparing what an employee receives at work with what is expected, desired, and thought of as appropriate.

The work environment plays an important role in the company's success. The better the environment is, the more joyful employees are as they feel working at home as productively as they can. Not only that, they will also be able to release their best potential. Not just for the sake of salary, they do it for the long-term progress of the Islamic Hospital in Surabaya. The positive energy and the excitement of the paramedics in each unit was good on average. It possibly means that the paramedics enjoy working in their team and unit. The respect of the Islamic Hospital in Surabaya towards the paramedics was mostly good, so the employee job satisfaction increased and resulted in a positive performance.

\section{CONCLUSION}

This study showed that patient satisfaction in terms of hospital hygiene was low in the inpatient rooms of the Islamic Hospital in Surabaya. In addition, patients also felt dissatisfied with the results of the health examination while being treated. They were also less satisfied with the paramedics' empathy in the Multazam Room. This study discovered a significant relationship between people equity and patient satisfaction. Internalizing an organizational culture is essential to harmonize the goals, vision, and mission between the hospital and its employees. This study recommends that there should be a more serious evaluation of the cleanliness of all service units at the Islamic Hospital in Surabaya.

\section{REFERENCES}

Becker, G. (1994) Human Capital: A Theoretical and Empirical Analysis with Special Reference to Education (3rd Edition). National Bureau of Economic Research, Inc. Available at: https://econpapers.repec.org/RePEc:nbr:nbe 
rbk:beck94-1.

Camgöz-Akdağ, H. (2010) 'Quality of health care and patient satisfaction: An exploratory investigation of teh 5Qs model at Turkey', Clinical Governance: An International Journal, 15(2), pp. 92-101.

Carmeli, A. (2004) 'Strategic human capital and teh performance of public sector organizations', Scandinavian Journal of Management, 20(4), pp. 375-392.

Chu, S. D. and Khong, T. S. (2018) 'Measuring healthcare service quality in a private hospital in a developing country by tools of Victorian patient satisfaction monitor', Journal of Hospital Administration, 7(5), pp. 1-7.

Diharto, A. K., Budiyanto and Muafi (2017) 'A causality model of people equity, VRIN resource, social capital, innovation capability and SMEs performance', Journal of Business and Retail Management Research, 11(4), pp. 124-130.

Finney, M. I. (2008) Building High-Performance People and Organizations. California: Praeger.

Kreitner, R. and Kinicki, A. (2007) Organizational Behaviour. 7th edn. New York: Mc Graw Hil.

M, D. K., Chengappa, S. and Pandya, S. (2013) 'Capability Development: Enhancing Employee Potential through Strategic Competency Building and People Development', International Journal of Management and Social Sciences Research, 2(2), pp. 27-32.

Mishra, P. H. and Mishra, T. (2014) 'Study of Patient Satisfaction at a Super Specialty Tertiary Care Hospital', Indian Journal of Clinical Practice, 25(7), pp. 624-634.

Parasuraman, A., Zeithaml, V. A. and Berry, L. L. (1998) 'SERVQUAL: a multiple item scale for Measuring consumer perceptions of service quality', Journal of Retaling, 64(1), pp. 12-40.

Phillips, P. (1993) 'A deconstruction of caring', Journal of Advanced Nursing, 18(10), pp. 1554-1558.

Puspitasari, S. T. (2018) Upaya Peningkatan Kepuasan Pasien Berdasarkan People Equity di Unit Rawat Inap Rumah Sakit Islam Surabaya. Master Thesis. Airlangga Unversity.

Ramseook-Munhurrun, P., Lukea-Bhiwajee, S. D. and Naidoo, P. (2010) 'Service Quality In The Public Service', International Journal Of Management And Marketing Research, 3(1), pp. 37-50.

Schiemann, W. A. (2006) People equity: a new paradigm for measuring and managing human capital, Human Resource Planning. Available at: http://go.galegroup.com/ps/anonymous?id=G ALE\%7CA144869297\&sid=googleScholar\&v $=2.1$ \& $\mathrm{it}=\mathrm{r}$ \&linkaccess $=\mathrm{abs} \& \mathrm{issn}=01998986 \&$ $\mathrm{p}=\mathrm{AONE} \& \mathrm{sw}=\mathrm{w}$ (Accessed: 10 September 2018).

Schiemann, W. A. (2013) 'From talent management to talent optimization', Journal of World Business.

doi: http://dx.doi.org/10.1016/j.jwb.2013.11.012.

Swanson, K. . (2013) 'Empirical Development of a Middle Range Theory of Nursing', in Caring in Nursing Classics. Marlaine C. New York: Springer, pp. 211-221.

Vinodkumar, S., Varghese, B. G. and Setia, M. S. (2018) 'Factors associated with patient satisfaction in a private health care setting in India: A cross-sectional analysis', Journal of Hospital Administration, 7(4), pp. 44-51. 